\title{
Marketing strategy of ornamental crops growing in Ukraine at the present stage
}

\author{
Yezhov V. ${ }^{1}$, Lytovchenko . $^{2}$ \\ Institute of horticulture of NAAS \\ 23 Sadova Str., Novosilky village, Kyiv-Sviatoshyn region, Kyiv oblast, Ukraine, 03027 e-mail: \\ 1ezhow.valeriy@gmail.com, 2apl83@ukr.net
}

The purpose. To determine the main components of the marketing strategy for the development of ornamental crops plant growing in Ukraine. Methods. Historical-scientific, problem-chronological, logical. Materials of statistical observations in Ukraine and the EU as well as price lists of ornamental plant producers were used and analyzed. Results. The analysis is made of the main components of the market of ornamental crops in Ukraine - production, assortment, pricing policy, sales channels, export and import of products, total capacity. It is established that the domestic market of ornamental plants has changed dramatically over the past 20 years and despite two economic crises continues to develop. That is confirmed by the increase over the last 4 years of its production by $14 \%$, the volume of retail trade twice, the total market capacity by $51.4 \%$, and the revival since 2016 of exports. Along with the positive changes, this segment of the agricultural complex has weaknesses - limited range, too long sales logistics, excessive concentration of production in the capital region, unreasonable increase in prices for some products, small volumes, and limited export geography. Based on the analysis, the main elements of the marketing strategy of ornamental crops at the present stage are proposed: expanding the range, optimizing sales channels, equalizing its volumes in the regions, regulating prices based on new products, increasing the share of domestic retail sales and increasing exports. Conclusions. The analysis of the main components of the market of ornamental plants in Ukraine is carried out, its positive and negative sides are established. Based on the analysis, a marketing model of the development strategy of this segment of agricultural production is proposed.

Key words: ornamental plants, domestic market, product range, prices, logistics, development strategy model.

DOI: https://doi.org/10.31073/agrovisnyk202011-04

Modern production of ornamental plants has developed in Ukraine at the turn of the XX and XXI centuries, gradually replacing the outdated concept of Soviet "green buildings". It so happened that this segment of the agricultural complex survived with it over the next 15-20 years two powerful economic crises $-2008 / 2009$ and $2014 / 2015$, but in both cases showed sufficient resilience and ability to further development [1]. Currently, one of the urgent problems of ornamental crop production is the development of marketing strategy, which would include not only information and analytical support (production structure, technologies used, product range, prices, sales logistics, imports and exports, etc.), but also recommendations for improving these indicators. There is very little research in this area in Ukraine, for example, the work of Chernyaeva [2] on the marketing of domestic flower products, which is an important component of this problem, but covers only part of it. Thus, the purpose of this study is to determine the main components of the marketing strategy for the development of ornamental plants in Ukraine.

Materials and methods. The articl uses historical-scientific, logical, problem-chronological research methods, uses and analyzes materials of official statistical observations in Ukraine and the EU, information from the sites of leading companies for growing ornamental plants.

Results. After the crisis of 2014/2015, the market of ornamental plants in Ukraine shows a steady upward trend (Table 1).

1. The main components of the market of ornamental plants in Ukraine |

\begin{tabular}{|c|c|c|c|}
\hline \multirow[t]{2}{*}{ Indicator } & & \multicolumn{2}{|c|}{ Value, UAH million } \\
\hline & & 2016 & 2019 \\
\hline Wholesale & 732,0 & & \\
\hline Retail sale & 530,1 & & \\
\hline Own production & 474,7 & & \\
\hline Import & 276,7 & & \\
\hline Export & 85,8 & & \\
\hline Total & 898,6 & & \\
\hline
\end{tabular}


While wholesale sales have increased by only $14 \%$ in recent years, domestic production has grown by $22 \%$ and retail sales have doubled. Imports and exports also increased, and total market capacity increased by $51.4 \%$. We will note that sale of ornamental plants at retail for one person for a year changed for this period from 13,3 to 28,6 UAH. Although the increase looks significant, in general it is significantly lower than the leading European countries: in 2013 in Poland this figure was 69, in Germany 127, and in the Netherlands $343 \mathrm{UAH}$. [3]. Importantly, despite a significant increase in imports of ornamental plants, the balance of their retail sales remained virtually unchanged, $51 \%$ of domestic production in 2016 and $52 \%$ in 2019 . As for exports, with the overall positive dynamics, it remains too small: currently Ukraine ranks 75 th in the world with a share of $0.02 \%$ of world volume [4]. The same can be said for production volumes: last year they amounted to 6.7 billion $€$ in the Netherlands, from 2.7 to 2.8 billion $€$ in France, Germany and Italy, and together in the EU (excluding the UK) 20, 6 billion $€$ [5]. As for the export of cut flowers, almost $80 \%$ of its volume falls on the Netherlands, Colombia and Ecuador [6].

Important for assessing the characteristics of the market of ornamental plants is the structure of imports of these products (table 2).

\section{Import of ornamental plants to Ukraine}

\begin{tabular}{|c|c|c|c|}
\hline \multirow[t]{2}{*}{ Indicator } & & \multicolumn{2}{|c|}{ Value, UAH million } \\
\hline & & 2015 & 2019 \\
\hline Bulbs, tubers & 56.3 & 110.6 & \\
\hline Bulbous flowers & 26.0 & 64.7 & \\
\hline Rose bushes & 17.5 & 14.0 & \\
\hline Roses cutting & 45.5 & 110.6 & \\
\hline Carnation cutting & 42.0 & 27.2 & \\
\hline Chrysanthemum cutting & 42.0 & 58.2 & \\
\hline In total with others & 276.7 & 434.4 & \\
\hline
\end{tabular}

Over the past 4 years, imports of flowers to Ukraine increased by $36.3 \%$ and amounted to UAH 434.4 million. In the range of imports, about $25 \%$ falls on tubers and bulbs, the same amount on roses; the third is the proportion of flowers of bulbous crops. Note the rather limited range of imported flower products and the geography of imports - for example, all tubers and bulbs with chrysanthemums come from the Netherlands, roses - from Colombia, Ecuador and Kenya, carnations - from Turkey. Another characteristic feature of imports is a constant decrease in the unit cost of production: from 2013 to 2019 in the group of roses it fell from 4.5 to $1.95 \mathrm{UAH}$, chrysanthemums - from 3 to $1.47 \mathrm{UAH}$, carnations - from 1.8 up to UAH 0.95

An equally important factor in assessing the market of ornamental plants is the structure of retail trade (table 3).

It can be stated that over the last 7 years the share of sales of flowering plants in the leading regions has decreased significantly, the most in Donetsk and the least in Dnipropetrovsk regions. Against this background, the share of sales in Kyiv and the region, as well as in other leading regions, increased significantly. For example, the share of sales in Sumy, Zaporizhia and Ivano-Frankivsk region increased to about $3 \%$.

\section{Structure of retail trade}

\begin{tabular}{|l|cc|}
\hline Region & \multicolumn{2}{|c|}{ Sale, \% from total } \\
\cline { 2 - 3 } & $\mathbf{2 0 1 3}$ & $\mathbf{2 0 1 9}$ \\
\hline Kyiv & 27,0 & 45,9 \\
Lviv & 13,1 & 6,2 \\
Donetsk & 13,0 & 1,5 \\
Kharkiv & 10,2 & 4,4 \\
Dnipropetrovsk & 8,1 & 6,5 \\
Odesa & 10,0 & 5,5 \\
Other regions & 18,6 & 29,2 \\
\hline
\end{tabular}

Our further research has shown that over the last three years the sales channels of ornamental plants have remained virtually unchanged: for example, $20-25 \%$ of tree ornamental crops are sold through specialty stores, $20-30 \%$ through garden centers, another $20-30 \%$ through the Internet. -shops, 
up to $20 \%$ - through the market and street trade and only $5-8 \%$ through supermarkets. The logistics of the sale of ornamental plants are also quite clear. Thus, for imported products, it includes the following stages $[3,4]$ : foreign auction centers $\rightarrow$ domestic logistics companies (importers) $\rightarrow$ large wholesale companies $\rightarrow$ small wholesale companies $\rightarrow$ retail enterprises. A significant disadvantage of this logistics is that at a satisfactory level in terms of range and quality of products, it provides only the capital, while wholesale supplies in the region can take place once a week, and at the district level generally flourishes spontaneous trade.

We analyzed the production structure and assortment of products in three climatic zones of Ukraine (table 4). It is shown that in these zones there are concentrated about 200 enterprises for the production of ornamental plants, of which about 120 are private. According to [7], except for forest nurseries in Ukraine, ornamental plants are grown about 400 enterprises located on an area of about 3000 hectares and 320 of them are private. According to other data [8], in Chernihiv region as part of the Forest-Steppe there are 47 nurseries of decorative crops, which provide local 101 retail enterprises with a share of cut flowers $83 \%$.

It's interesting that most nursery decorative crops are small, with an annual sales volume of up to 300 thousand $\mathrm{UAH}$, and enterprises with annual financial achievement of more than UAH 1 million in the region are only 11 .

\section{Production of ornamental plants in Ukrainian climate zones}

\begin{tabular}{|c|c|c|c|c|}
\hline Indicator & & $\begin{array}{l}\text { Forest } \\
\text { Steppe }\end{array}$ & Steppe & Polissya \\
\hline \multicolumn{5}{|l|}{ Number of productions } \\
\hline -total & 72 & 74 & 53 & \\
\hline - state enterprises & 25 & 28 & 22 & \\
\hline - private enterprises & 47 & 46 & 31 & \\
\hline \multicolumn{5}{|c|}{ Number of productions with volume of production, UAH } \\
\hline- up to 300,000 & 40 & 55 & 42 & \\
\hline- up to $1,000,000$ & 25 & 17 & 9 & \\
\hline -more than $1,000,000$ & 7 & 2 & 2 & \\
\hline \multicolumn{5}{|c|}{ Number of plant's varieties } \\
\hline -total & 150 & 120 & 115 & \\
\hline -trees & 70 & 50 & 48 & \\
\hline -bushes & 40 & 30 & 30 & \\
\hline -flowers & 20 & 20 & 20 & \\
\hline -herbal perennials & 20 & 20 & 17 & \\
\hline
\end{tabular}

As for the range of products, it is extremely limited - in areas from 115 to 150 species of ornamental plants, most of which are wood ornamental plants and much less - herbaceous deciduous and flower crops.

Against the background of growth in the production of ornamental plants in the country after the crisis, product prices have undergone a significant transformation (Table 5). The presented data clearly show not only the rapid rise in prices, especially in recent years for ornamental wood crops (2-5 times), but also their regulation due to market saturation: in particular, during the study period, prices for spindle tree, , box tree and juniper decreased. Significantly smaller changes occurred in the prices of ornamental plants in containers. In general, this year the price of some ornamental crops of domestic production exceeded the price of similar crops, in particular Hungarian nurseries - this applies to catalpa, spruce, western thuja and maple. In [9] it is stated that most of the ornamental plants planted in Ternopil were imported mainly from Poland and Germany; the competitive advantage of these products is high decorativeness, standard packaging and price, even at additional costs for customs clearance and transportation. 
5. Prices on the ornamental plants in Ukraine

\begin{tabular}{|c|c|c|c|c|}
\hline \multirow{3}{*}{$\begin{array}{l}\text { Ornamental } \\
\text { culture }\end{array}$} & \multicolumn{4}{|c|}{ Price of one, UAH, by the groups } \\
\hline & \multicolumn{2}{|c|}{$\begin{array}{c}\text { Open ground, } 3 \text { (bushes 2) years } \\
\text { old }\end{array}$} & \multicolumn{2}{|c|}{ Container, 2-3 L } \\
\hline & 2016 & 2019 & 2016 & 2019 \\
\hline Birch & 245 & $850(1530 *)$ & 155 & 460 \\
\hline Maple & 300 & $750(500)$ & 155 & $350(90)$ \\
\hline Catalpa & 350 & $715(300)$ & 190 & 100 \\
\hline Pine & 150 & 750 & 95 & $360(180)$ \\
\hline Spruce & 140 & $830(380)$ & 160 & $210(200)$ \\
\hline Thuja western & 180 & $460(250)$ & 150 & $180(90)$ \\
\hline Spindel tree & 70 & $65(105)$ & 270 & $150(140)$ \\
\hline Lilac & 110 & $450(650)$ & 130 & $220(45)$ \\
\hline Box tree & 140 & $125(110)$ & 160 & $105(45)$ \\
\hline Juniper & 180 & $120(440)$ & 190 & 170 (120) \\
\hline
\end{tabular}

Another aspect of assessing the modern production of ornamental crops is the use of technology. In our previous work [10] it was shown that domestic nurseries of ornamental crops widely use modern world technologies for growing ornamental plants, which are based on the use of cartoon seedling cultivation, stimulators of root formation and plant growth, disease protection, container growing seedlings and more. In addition, it should be noted that a significant part of nurseries practice growing annual seedlings purchased abroad.

This analysis allows us to conclude about the significant prospects for further development of ornamental crops in Ukraine and to propose the main components of the marketing model to ensure this process.

The range should be expanded by attracting new species of flowering and deciduous herbaceous plants, lawn grasses, mastering the full cycle of growing bulbous and tuberous ornamental crops, developing a new direction in ornamental crops - creating crops with dual functions (ornamental aromatic, ornamental medicinal, ornamental fruit).

Production optimization includes the use of a full cycle of growing ornamental crops, the use of new varieties of domestic origin, microclonal propagation technologies, the creation of new enterprises mainly outside of Kyiv and the region, a gradual reduction in the number of small producers.

Optimization of sales should include reducing the logistics, the time of passage of goods through it, expanding logistics to areas and small towns, competitive displacement of street sales of ornamental plants, equalization of sales by region according to population.

Optimization of pricing policy includes constant marketing support of the product market, establishing a balance between price and demand, extensive use of the factor "novelty" (according to available data [11], the price of new varieties in the first year of sale $40-50 \%$ higher than already mastered products).

Optimization of export and import of products should provide expansion of volume and geography of export at the expense of high quality and the optimum price of production, the further shift of balance of retail sale of ornamental plants in favor of domestic production, first of all at the expense of increase in volumes and assortment of flowers.

\section{Conclusions}

The analysis of the main components of the market of ornamental crops in Ukraine is carried out, its positive and negative sides are established. Based on the analysis, a marketing model of development strategy for this segment of agro-industrial production is proposed.

\section{References}

1. Yezhov, V.M., Lytovchenko, O.P. (2016). Rynok dekoratyvnykh roslyn Ukrainy v umovakh suchasnoi ekonomichnoi kryzy [Market of ornamental plants of Ukraine in the current economic crisis], Bulletin of Agricultural Science, 12, 20-24 [in Ukrainian].

2. Cherniaieva, A.N. (2011). Metodychni pidkhody do formuvannia marketynhovykh prohram prosuvannia kvitkovoi produktsii [Methodical approaches to fordevelopment of marketing programs 
to promote forging products]. Bulletin of the Khmelnytsky National University, 2(6), 124 - 127. [in Ukrainian].

3. Butko, M.P., Solomakha, I.V. (2017). Stanovlennia vitchyznianoho rynku florystychnoi produktsii v umovakh yevrointehratsii [Formation of the domestic market of floristic products in the conditions of European integration]. Chernihiv: ChNTU. [in Ukrainian].

4. Kleefmangroup (2019). Rynok kvitiv ta dekoratyvnykh roslyn v Ukraini. Skorochenyi zvit Posolstvu Niderlandiv $v$ Ukraini [Market of flowers and ornamental plants in Ukraine. Short report to the Embassy of the Netherlands in Ukraine]. http: www.agroberichtenbuitenland.nl.

5. European Commission. Flowers and ornamental plants - production. Statistics 2010-2019. Working document of EC, unit G.2 of DG Agri. February 2020.

6. Sorokina, S.V. (2016). Tovaroznavstvo kvitiv [Commodity science of flowers]. A textbook. Kharkiv, KhDUKhT. [In Ukrainian].

7. Kosenko, Yu.I. (2017). Suchasnyi stan dekoratyvnoho rozsadnytstva Ukrainy ta perspektyvy yoho rozvytku [The current state of ornamental planting in Ukraine and prospects for its development]. Scientific Bulletin of NULES. Series Forestry and ornamental horticulture, 266, 170-177 [in Ukrainian].

8. Solomakha, I.V. (2024). Stanovlennia pidpryiemstv na rynku kvitkovo-dekoratyvnoi produktsii Chernihivskoho rehionu [Formation of enterprises in the market of flower and decorative products of the Chernihiv region]. Scientific Bulletin of Kherson State University. Economic Sciences Series, 8(6), 110-113. [In Ukranian].

9. Tobilevych, H.N. (2019). Problemy ta perspektyvy rozvytku rynku dekoratyvnoho roslynnytstva u m. Ternopil [Problems and prospects of development of the market of ornamental plant growing in Ternopil]. Scientific reports of NULES. Forest series and park management, 6(82). doi: 10.31548/dopovidi 2019.06.023 [In Ukranian]

10. Ezhov, V.M., Pishchenko, O.V., Lytovchenko, O.P. (2017). Tekhnolohichni ta ekonomichni chynnyky zrostannia vitchyznianoho vyrobnytstva dekoratyvnykh kultur [Technological and economic factors of domestic ornamental plants production growth], Bulletin of Agricultural Science, 10, 15-18. [In Ukranian]

11. Obolientseva - Krasovska, O.S. (2017). Osoblyvosti vstanovlennia vartosti novykh vydiv pry provedenni sudovo-tovarnoi ekspertyzy [ Features of establishing the value of new species during forensic examination]. Theory and practice forensic science and criminology, 17, 351-359. [ In Ukranian]. 